\title{
Becoming A Dominant Misinterpreted Source: The Case of Ferdinand De Saussure in Cultural Sociology
}

\author{
Dustin S. Stoltz \\ University of Notre Dame ${ }^{1}$
}

Cultural analysts in sociology typically cite the work of Ferdinand de Saussure to motivate a narrow theory of meaning. In so doing, sociologists incorrectly attribute to Saussure: (1) the postulate that meaning is arbitrary (2) the idea that signs gain meaning only through relations of opposition to other signs, and (3) the view that there is an isomorphic correspondence between linguistic signs and all cultural units of analysis, ergo culture is fundamentally arbitrary, and finally (4) he offers a Durkheimian theory of culture (i.e. Saussure was follower of Durkheim). Saussure's project, rather, was specific to linguistics, and mainly one of theoretical and methodological clarification regarding phonology. Saussure never intended his analytical model of phonology to apply to the real operation of meaning in general, as done by contemporary interpreters and, furthermore, never argued that meaning is arbitrary.

Keywords: Saussure, Durkheim, Linguistics, Cultural Sociology, Arbitrary, Meaning

\footnotetext{
${ }^{1}$ This paper was awarded the 2018 Graduate Student Paper Award from the History of Sociology Section of the American Sociological Association. I would like to thank Omar Lizardo, Vanina Leschziner, and Michael Wood for helpful comments on previous drafts.
} 
Sociologists often cite Ferdinand de Saussure to assert that the meaning of cultural elements is fundamentally arbitrary and that signs gain meaning only through relations of opposition to other signs. ${ }^{2}$ That is, rather than interpreting Saussure as primarily contributing to the philosophy of linguistics (i.e. how language is to be studied as a science), sociologists read his work as foremost an intervention in the philosophy of language (i.e. how language refers to reality). This reading is often presented as a fundamentally Durkheimian theory of culture, because, it is assumed, Saussure was a follower of Durkheim. This received intellectual history, however, is flawed. First, there is no evidence that Durkheim influenced (the institutionally older) Saussure. Second, Saussure never intended his analytical model of phonology to apply to the operation of meaning in general. Finally, and most importantly, Saussure never claimed that linguistic meaning is arbitrary or that signs gain meaning only through relations of opposition to other signs.

Reviewing 167 articles and book chapters written by sociologists (from 1969 to 2018) which refer to the lecture notes collected in Saussure's Course in General Linguistics (Cours), I find the most common citation is highly ritualistic (in that only thirty-five even provide page numbers), and often used to evoke (approvingly or disapprovingly) the notion that languages, signs, or meaning in general, is arbitrary. Among those offering page numbers, citations are confined to very few places and used to motivate two general arguments. For the first argument, sociologists cite sections on the "linguistic sign" (pp. 65-66) and the role of difference in producing "linguistic value" (pp. 114-120), to assert meaning is arbitrary and signs gain meaning through relations of opposition to other signs. Second, sociologists cite the section outlining the distinctions between langage, langue, and parole (p. 14) and defining the study of "semiology" (p. 16), to argue there is an isomorphic correspondence between linguistic signs and all

\footnotetext{
${ }^{2}$ For examples, see (Kane, 1991, p. 56; Zerubavel, 1987, pp. 347-8; Alexander, 1988, pp. 4-5, 2006 , p. 566, 2013, pp. 33, 174; Wuthnow, 1989, p. 39; Alexander and Smith, 1993, pp. 157, 202; Emirbayer, 1997, p. 300; Reed and Alexander, 2009, p. 387; Knight and Reed, 2019, p. 241)
} 
cultural units of analysis (ergo culture is fundamentally arbitrary). This selective appropriation leaves out the vast majority of the Cours. ${ }^{3}$

Regarding the first claim, many credit Saussure for defining the linguistic sign in terms of a dualism between physical sound and physical object (i.e. both external to individuals). Saussure's key innovation, however, was putting forth a psychological dualism: between the "mental image" of the sound pattern and the mental "concept," both of which were entirely "interior," psychological phenomena. This allows for the bracketing of questions of linguistic meaning or "reference" (Dickens, 1990, p. 154), and with it, most of what is considered the core territory of the philosophy of language. In Saussure's words, regarding the "non-linguistic domains of pure thought... It is not for the linguist to determine exactly where the independence of the vocal sign can be said to begin, whether certain categories pre-exist and others post-exist the vocal sign" (Saussure, 2006, p. 26). To put it explicitly, in the Cours, Saussure never claimed that meaning is arbitrary. Rather, "Saussure's arbitrariness lies in the relation between signifier and signified, not in the relation between the concept signified and the world" (Elder-Vass, 2014, p. 257).

Second, sociologists often presume Saussure did not intend for his work to be "confined to linguistics alone" (Zerubavel, 2004, p. 185), he did, after all, coin the term "semiology" ([1986] 2009, p. 12). ${ }^{4}$ However, in most ways he did wish to confine his work to linguistics. "Saussure's whole effort, ignored by his borrowers, was to emphasize the singularity of language, everything that separates it from other social practices or forms" (Anderson, 2016, p. 43 original emphasis). In Saussure's words: “Whitney said 'language is a human institution.' ...but, by its very nature, any unfortunate analogy with

3 Entirely omitted are Saussure's discussion of grammar, principles of phonology and articulation, diachronic (i.e. evolutionary) linguistics, geographic linguistics, and retrospective (or historical/anthropological) linguistics.

${ }^{4}$ Named after the Greek word sēmêion, which means "sign" or "mark." Original passage in French (Saussure 1916:33-4 original emphasis): "On peut donc concevoir une science qui étudie la vie des signes au sein de la vie sociale; elle formerait une partie de la psychologie sociale, et par conséquent de la psychologie générale; nous la nommerons sémiologie (du grec semeîon, "signe")." English translation (Saussure [1986] 2009:38 original emphasis): "It is therefore possible to conceive of a science which studies the role of signs as part of social life; it would form a part of social psychology, and hence of general psychology. We shall call it semiology (from the Greek semeîon, "sign")." 
any other human institution, except writing, can only misrepresent its real essence" (Saussure, 2006, pp. 146-147 original emphasis). Although Whitney-the eminent American linguist - both argues that language is arbitrary and a human institution, Saussure argues, "he failed to see that this arbitrary character fundamentally distinguishes languages from all other institutions" (Saussure, [1986] 2009, p. 88 see also pp 32, 37-38, 96-98, 102). Some may argue Saussure at least presumed "semiological systems" operated as language, and yet again he warns against such a presumption. ${ }^{5}$ As the "units" of language, according to the Saussurean model, are not the perceptible phenomena of speech (but rather their mental impressions) this "distinguishes languages from all other semiological institutions" (Saussure, [1986] 2009, p. 130). Additionally, while Saussure knew that language is not entirely unmotivated (e.g., Saussure, [1986] 2009, pp. 80, 157), Saussure believed it was the most arbitrary of semiological institutions, and therefore an entirely unique kind of phenomena.

In this paper, I demonstrate that mapping Saussure's model of phonology — as a system of values produced by oppositions - onto the operation of meaning in general misunderstands his contribution to linguistics. I begin with an intellectual biography of Saussure which allows us to see the sort of phonological phenomena toward which he was oriented. This is followed by a consideration of the possibility that Durkheim influenced Saussure, a common, yet dubious, claim by sociologists. Following this, I engage in an exegetical discussion of Saussure's work by outlining the basic components of his model, noting the most common misinterpretations by sociologists.

\footnotetext{
${ }^{5}$ This is also the fallacy of linguistic analogy (Gottdiener, 1985): "since all languages are made up of words and all words are signs, all things made up of signs are languages” (Krampen, [1979] 2013, p. 308).
} 


\section{Prelude to the Saussurean Model}

\section{Ferdinand De Saussure and 19th Century European Philology}

\section{Early Years in Geneva: Adolphe Pictet and Port-Royal}

Saussure was born in Geneva in 1857- the same year as Thorstein Veblen, a year after Sigmund Freud, and a year before Emile Durkheim, Georg Simmel, and Franz Boas-and began studying languages at an early age. He mastered elementary Greek by eleven and continued to study Greek through his middle school and secondary school at the Collège de Genève, before attending the preparatory school, Gymnase de Geneve. During his adolescent and teenage years, Saussure was inspired by the Swiss linguist and distant relative, Adolphe Pictet, who introduced Saussure to the theoretical study of the "Indo-European" languages, first as his neighbor circa 1870, and a few years later when Saussure read Indo-European Origins of the Primitive Aryans (Bouissac, 2010, pp. 38-9).

Motivated by this book, the young Saussure wrote the "Essay for reducing the words of Greek, Latin and German to a few roots," which he sent to Pictet in the fall of 1874 (almost a year before the latter passed away). "This piece of juvenilia," as Saussure would describe it later, "consisted of a proof that all goes back, in all possible languages, to radicals immediately constituted of 3 consonants (more anciently still of 2 consonants)" (Joseph, 2012b, p. 154). It was his first attempt at a general theory of language (completed when he was 17, it was published posthumously in 1960).

Additionally, an important, if unacknowledged, ${ }^{6}$ influence on the young Saussure was his philosophy and psychology teacher at the Gymnase, Antoine Verchère, as well as André Oltramare who was the director of the Collège, and later his teacher at the Gymnase and Université de Genève. The

\footnotetext{
${ }^{6}$ Foucault $(2012$, pp. 67, 286) briefly notes Saussure "rediscovered" the Port-Royal approach to language (see also Descombes, 2016).
} 
Saussure scholar, John Joseph (2012b, pp. 80-82), notes that Verchère and Oltramare's pedagogical approach to teaching grammar and logic was directly linked to the philosophy of "Port-Royal," associated with the heretical Catholic "Jansenist" monastery in Port-Royal-des-Champs, France. Most famously, this intellectual movement was associated with Antoine Arnauld and Pierre Nicole's Port-Royal Logic, a tome first completed in 1662, with the fourth and final in 1683, and the most influential text on the subject prior to the nineteenth century. However, they also produced one of the pioneering works on the philosophy of language and linguistics: Port-Royal Grammar.

Secondary schools in France had abandoned Port-Royal in the classroom, but not Geneva-primarily due to the enterprising work of Louis Longchamp, who successfully got his Latin grammars into the school curriculum during Oltramare and Verchère's formative years (Joseph, 2012a). According to Joseph, "Some of the principal ideas associated with Saussure's name" can be found in Verchère's course notes, for example "the distinction of langage, langue, and parole, language as a collection of signs, value, conventional signs, language as a system of signs" (2012b, p. 144).

\section{The Encounter with Herodotus}

No introduction to Saussure is complete without the following story (Bouissac, 2010, p. 40), which according to the man himself some thirty years later "remained as though photographed in my memory" (Joseph, 2012b, p. 133). At the College, prior to his acceptance into the more prestigious Gymnase, Saussure was first introduced to the existence of dialects in Greek. Previously he only studied the type of Greek spoken by the philosophers of Athens (the Attic dialect). While reading the work of the historian Herodotus, Saussure encountered a new variant (the Ionic dialect). Famously, and perhaps not without elements of folklore, during the 1872-73 academic year Saussure struck upon the intellectual kernel that would fuel his entire project thereafter. 
The episode is often reduced to Herodotus's use of "tetakhatai" (they have been arrayed). Saussure had yet to read this word because in Attic Greek, rather than a single a conjugated word, it is rendered as a phrase. What was curious to Saussure, is that, by analogy to similarly conjugated words — which he described as "a flash of lightning that I received instantaneously" (Joseph, 2012b, p. 133) - the root tetakh- should take the ending form -ntai, which would form tetagntai (with the $/ \mathrm{kh} /$ "softening" to a /g/).

To oversimplify the fifteen-year-old's puzzle, how could the Greek consonant $/ \mathrm{n} /$ become the vowel /a/? His presumption was that pronouncing three consonants in a row is a difficult physiological feat. Attic Greek solved it by rendering it as a phrase (a syntactic solution), while Ionic Greek solved it by altering the sounds in the word (a phonological solution). Saussure's solution was to posit the existence of a kind of sound, one that could either be a vowel or consonant depending on the adjacent sounds, in the ancestral language from which Greek emerged.

Linguistics in the 19th century was dominated by "comparative and historical linguistics," more properly the study of historical texts (i.e. philology). The "holy grail" of the study of language during that time was the reconstruction of a hypothetical ancestral language that could explain similarities between geographically dispersed language communities (Sanskrit, Greek, Persian, Armenian, and various other European groups) through a kind of evolutionary theorizing. Indeed, many philologists took it for granted that this hypothetical language (referred to as "Proto-Indo-European" or "PIE") was a "perfect" language - building upon millennia of tropes of Adam and Eve speaking such a language with God in the Garden of Eden (Eco, 1995) — that had undergone subsequent decay. ${ }^{7}$ In any case, the young

\footnotetext{
7 Some scholars were far more explicit regarding the link to the evolution of the "human races" (Eco, 1995). For example, Pictet's work was used as evidence that the "Aryan race" was superior, specifically, to the "Semitic races." (see Joseph, 2012b, pp. 150-2)
} 
Saussure - in his Greek revelation, and his ambitious essay for Pictet—was already attempting to make a contribution to this project.

\section{The University of Leipzig and the Neogrammarians}

Saussure studied the natural sciences for one year at the Université de Genève before moving to the University of Leipzig, the epicenter of Indo-European linguistics, in 1876 (Joseph, 2012b, p. 184). Upon arriving, he found the younger faculty in the middle of an intellectual movement — referred to as the Junggrammatiker (Neogrammarians). Although some paint Saussure's work as a rejection of his contemporaries, his approach is mostly commensurate with them, the Neogrammarians in particular (Davies, 2004; Koerner, 2013). Among other things, this group of scholars sought to replace the then-dominant "Darwinian" framework, which presumed languages evolve like organisms (Koerner, 1983; Richards, 2002).

There were two prongs to the Neogrammarian approach to linguistic change: morphological/syntactic and phonological. Regarding the latter-the ways words are inflected and arranged in sentences to perform different grammatical functions - they posited that change primarily occurred through analogy. Regarding the former, which is more germane for our discussion, the central tenet was that sound changes are exceptionless. They transform unconsciously and according to definable sound laws. This stance was a generalization of “Grimm's Law," named after the folklorist who argued in 1819 that three sounds in Germanic languages $(/ \mathrm{f} /, / \mathrm{th} /, / \mathrm{h} /)$ corresponded to distinct, but different, sounds in PIE (/p/, /t/, /k/, respectively), regardless of the word. For example, /p/ in PIE would change to an /f/ as in "pisk" (in PIE) and "fish" (in Germanic languages). Wherever one would expect a /p/ from the PIE word, one would find an /f/ in the Germanic languages. Considering Saussure's prior proclivities, it is unsurprising that he was encouraged by the Neogrammarians position regarding phonology, and their general vision of linguistics as a systematic science rather than a descriptive enterprise. 
While studying Sanskrit for one year at the University of Berlin in 1878-overlapping with Georg Simmel, a doctoral student in philosophy-Saussure wrote a 300-page book, the Memoir on the Primitive Vowel System in Indo-European Languages, and the following year he submitted his dissertation on the genitive case in Sanskrit. The former was written independently of his doctoral work in 1879, but it secured Saussure's reputation as an up-and-coming linguist. In fact, while visiting Leipzig for his doctoral defense, the renowned philologist Franz Delitzsch (intellectual great-great-great-grandfather of Noam Chomsky) asked the twenty-one-year-old if he was related to "the famous de Saussure," the author of the Memoir (Joseph, 2012b, p. 258).

In the Memoir Saussure theorized the existence of two additional sounds in PIE-hypotheses partially validated decades later by Hittite scholars (Koerner, 1985, p. 339)—using a method he pioneered now referred to as "internal reconstruction" (Davies, 2004, p. 22). One key peculiarity of this work which his contemporaries took exception to (and which non-linguists may see as splitting hairs), is that Saussure says nothing about the actual "acoustic" qualities of the theorized sound(s) (Koerner, 1985, p. 331; Davies, 2004, p. 21). ${ }^{8}$ Indeed, this work reinforces characterizations of Saussure as standing heavily on the intuition that linguists should focus on the organization between sounds in the mind, rather than sounds themselves - demonstrating much continuity with the essay he wrote for Pictet as a teenager (Joseph, 2012a, p. 265).

\section{A Brief Interlude with Durkheim}

For sociologists familiar with Saussure, the omission of Durkheim may seem strange. In one of the earliest references to Saussure by a sociologist, Charles Lemert states "It is almost certain that Saussure, who lectured in Paris at the École des Hautes Etudes from 1881 to 1891, was influenced by

\footnotetext{
${ }^{8}$ Saussure refers to these as "sonant coefficients" or "coefficients sonantiques," and, while the latter are now referred to as "resonants," it is still debated whether Saussure actually thought of his hypothesized sounds as vowels or resonants.
} 
Durkheim” (1979, p. 933 fn 5, see also 2003, pp. 303, 310, 311). In the same year, Anthony Giddens made the same assertion (see also Giddens, 1978, p. 7, 1979, p. 9). Likewise Kronenfeld and Decker insinuate: "Saussure had taught in Paris (while Durkheim was elaborating his theory of society), and his student Meillet was a member of the Annee sociologique group" (1979, p. 505). In an interview, Alexander goes much further by claiming, “there is strong evidence that Saussure attended Durkheim's lectures at the Sorbonne and drew directly upon some of these core ideas" (Cordero, Carballo and Ossandón, 2008, p. 527). The claim of a direct Durkheim/Saussure connection is tenuous for three reasons. First, there is no evidence Saussure attended Durkheim's lectures. Second, Durkheim and Saussure's time in Paris overlapped by less than two years. ${ }^{9}$ Third, Durkheim was still a student whose renown would not reach fruition until well into the twentieth century (Lukes, 1985). Saussure, on the other hand, was already well established by the 1880 s.

Aside from the fact neither Saussure nor Durkheim ever reference one another, ${ }^{10}$ much of the basic seeds of Saussure's approach to language were planted during his teenage years. While he certainly refined them throughout his life, the rudiments of his approach were well-developed by the time he completed his dissertation in 1880. Durkheim, on the other hand, was just beginning his academic journey in 1879 at the École Normale Supérieure.

Just prior to completing his doctorate, Saussure moved to Paris in December 1880. By November the following year, at 23, Saussure became a lecturer at the École des Hautes Etudes, teaching Gothic, Old High German, and later Indo-European philology. Michel Bréal, a founder of linguistics in France, chose Saussure to take over his lectureship in comparative grammar, and in support of this recommendation,

${ }^{9}$ Saussure was given military leave from Geneva at the end of November, and is recorded as attending his first meeting of the Société de Linguistique on 4 December 1880 (Joseph, 2012b, p. 274). He remained in Paris until August 3rd, where he returned to military training until October 1st, after which he returned to Paris (Joseph, 2012b, pp. 278-9).

10 Furthermore, Steven Lukes, known for writing the definitive intellectual history of the life and work of Durkheim, can recall no evidence of Durkheim's interaction with Saussure (personal communication). 
Léon Renier wrote "Mr de Saussure, although still young, [is] already very famous and highly esteemed in the scholarly world" (Joseph, 2012b, p. 280). During this same period, Durkheim was working toward his agrégation while battling "serious illness" (Lukes, 1985, p. 64). Saussure, on the other hand, was very busy hobnobbing with Parisian linguists and his family's Genevese social circle in Paris, as well as attending courses in linguistics, the weekly meetings of the Société de Linguistique, and editing his dissertation for publication (Joseph, 2012b, pp. 274-279).

Following Durkheim's completion of the agrégation in 1882, roughly a year after Saussure began lecturing, Durkheim left Paris in October to teach philosophy at several provincial lycees in France until 1887 (Calhoun, 2012, p. 196). During the 1885-6 academic year he took a hiatus to visit German universities on a fellowship from the Ministry of Education (Clark, 1968, p. 44; Lukes, 1985, p. 85), while also completing a draft of his first major work and dissertation, The Division of Labor in Society. In 1887, upon completing his doctorate, Durkheim accepted a position on pedagogy at the Université de Bordeaux in the south of France, where he founded France's first sociology department in 1895, and L'Année Sociologique in 1896. He remained far from Paris until becoming the chair of education at the Sorbonne in 1902, eleven years after Saussure returned to Geneva. Taken together, we can dismiss claims "that Saussure attended Durkheim's lectures at the Sorbonne" (Cordero, Carballo and Ossandón, 2008, p. 527). ${ }^{11}$

Aside from claims of direct interaction, there is also conjecture that Saussure's approach to language is indirectly "Durkheimian" in some substantive way. Specifically, scholars draw attention to the resemblance between the terminology deployed by Saussure and Durkheim (Wiley, 1988, pp. 257-8; Firth, 1950, p. 4; Brown, 1978, pp. 149-51; Gane, 1983, p. 70; Maryanski and Turner, 1991, pp. 109-10; Emirbayer, 2004, p. 8). For example, Saussure does emphasizes the "social" and "conventional" nature of

${ }^{11}$ According to his biographer upon leaving for Geneva at the end of 1891, "He would pass through the French capital again, often on his way to visit Albertine [his younger sister] in England. But he never stayed long. The city held too many ghosts of dreams and projects unrealized" (Joseph, 2012b, p. 371). 
language. However, we can return to Meillet who wrote in a letter to the Russian linguist, Nikolai Trubetzkoy: "I was very surprised when I saw F. de Saussure assert the social character of language: I had come to this idea by myself and under other influences..."12 Second, Saussure references Whitney numerous times to motivate this view of language as conventional (as opposed to "natural") (Koerner, 1991, p. 59). ${ }^{13}$

The Durkheim/Saussure connection is perhaps most explicit in the work of Alexander. For example, he contends that "Saussure depended...on a number of key concepts that were identical with the controversial and widely discussed terms of the Durkheim school," and supports this assertion with: “[m]ost linguistic historians... have interpreted these resemblances as evidence of Durkheim's very significant influence on Saussure" (Alexander, 1988, pp. 4-5, see also 2011, p. 99). ${ }^{14}$ Who are these linguistic historians? Alexander cites the Polish linguist Witold Doroszewski (specifically 1933, pp. 89-90) and the British social anthropologist Edwin Ardener. Ardener, in turn, only suggests the connection in passing and also relies on Doroszewski (1933:90-91), "who clearly demonstrates the Durkheimian nature of Saussure's langue” (1971, pp. xxxii-xiv).

More generally, the common French structuralist story, at least in sociology, includes some pathway back through Lévi-Strauss to Durkheim, and places Saussure in the middle (e.g., Giddens, 1979, p. 9; Lemert, 2003). For instance Maryanski and Turner (1991, pp. 109-10), in reviewing the two "structuralisms" that emerged out of functionalism, argue that Lévi-Strauss "ignore[d] the Durkheimian tendency of Saussure" (see also Turner, 1987, p. 21 fn 4). In support of their assertion Saussure "probably

12 “J'ai été bien étonné quand j'ai vu F. de Saussure affirmer le caractère social du langage: j'étais venu à cette idée par moi-même et sous d'autres influences..." dated the 25th of December, 1930 (Hagège, 1967, p. 117; cited in Koerner, 1987, p. 20)

${ }^{13}$ Saussure met Whitney in Berlin while the latter was meeting with Sanskrit specialists and looking at proofs of the German translation of his book Sanskrit Grammar. Not only did Saussure write of his admiration of Whitney, but we also know that Whitney read Saussure's Memoir and even offered notes given their mutual interest.

14 Note the resemblance to Washabaugh (1974, p. 27): "Most linguistic historians (Doroszewski 1933; Ardener 1971; Robins 1967; Mounin 1968) have interpreted these resemblances as evidence of Durkheim's influence over Saussure. However, a careful reading of Durkheim will show that these resemblances are only terminological." 
saw himself as a Durkheimian" (1991, pp. 109-10) they again cite Doroszewski (as does Jameson, 1974, p. 27; Sahlins, 1976, p. 111; Meštrović, 1987, p. 580; Rawls, 1996, p. 473).

\section{Witold Doroszewski and the Myth of the Durkheim/Saussure Connection}

Doroszewski's article was first presented at the Second International Congress of Linguists in Geneva (held August 25th-20th, 1931), and published in the French Journal de Psychologie in $1933 .{ }^{15}$ In it, he references the debates between Durkheim and Gabriel Tarde that took place shortly after Durkheim's return to Paris, at the Ecole des Hautes Etudes Sociales in 1903 (Tarde, 2010, pp. 136-140), and in various journals. Doroszewski claims that Durkheim was the direct inspiration for Saussure's concept of langue, while Tarde was the inspiration for the concept of parole. This is clearly articulated in the following passage from the conclusion:

F. de Saussure-I know from a certain source (je le sais de source certaine)-followed the philosophical debate between Durkheim and Tarde with deep interest. If one takes into consideration not only the idea, essential to Saussure, of "langue," but also the complementary idea of "parole," the whole of the Saussurean doctrine then appears as a curious attempt, by a linguist of genius, to reconcile the opposing doctrines of Durkheim and Tarde. In the opposition of "langue" to "speech" one sees the opposition of the Durkheimian notion to that of Tarde's. ${ }^{16}$

Interestingly, Doroszewski never claims Saussure and Durkheim had direct interaction while both in Paris in the 1880s. Rather, he claims the influence was from the Durkheim-Tarde debate. Second, he leaves the basis of the rumor unspecified. Presumably pressed on the matter, Doroszewski later claimed that this "certain source," was the former student of Saussure at Geneva, Louis Caille (Doroszewski, 1957, pp. 544, n3; see also Koerner Koerner, 1987, p. 20, cited in 2013).

${ }^{15}$ This 10-page article relies mostly on Durkheim's essay "Représentations individuelles et représentations collectives," published in Sociologie et Philosophie (Durkheim, 1924, see also the English translation 1974), citing it nine times, and Les règles de la méthode sociologique just four times.

16 "F. de Saussure - je le sais de source certaine - suivait avec un profond intérêt le débat philosophique engagé entre Durkheim et Tarde. Si l'on prend en considération non seulement l'idée, essentielle pour Saussure, de la "langue", mais aussi celle, complémentaire, de la "parole", l'ensemble de la doctrine saussurienne apparait alors comme une curieuse tentative, entreprise par un linguiste de génie, pour concilier les doctrines opposées de Durkheim et de Tarde. Dans l'opposition de la "langue" à la "parole" on entrevoit l'opposition de l'idée durkheimienne à celle de Tarde" (Doroszewski, 1933, p. 91). 
While Washabaugh (1974) authored the first essay in English debunking the Durkheim/Saussure connection (see footnote 13), the most sustained critic is the linguistic historian Koerner. Specifically regarding Doroszewski's article, Koerner references Antoine Meillet—perhaps the most important French linguist of the first half of the twentieth century, and Saussure's student and friend of twenty years (Joseph, 2000). After Saussure returned to Geneva permanently in 1891, Meillet took over his course on comparative linguistics, and as Meillet was also acquainted with Durkheim, ${ }^{17}$ he is an indispensable judge for such a claim. In the discussion with the audience following Doroszewski's 1931 presentation, Meillet rejected his conclusion outright (Koerner, 1971, p. 48). ${ }^{18}$

Koerner concludes that, while not impossible that Saussure knew of Durkheim, as it stands, there is no "convincing concrete, textual, evidence that Saussure incorporated Durkheimian sociological concepts in his theoretical argument" (Koerner 1987:22; see also Washabaugh 1974:28; Joseph, 2012b, p. 508). Furthermore, the high status Durkheim occupies in recent sociological theory is anachronistically superimposed onto the European academia of his day (i.e. a presentist reading). However, as Connell (1997, p. 1513) reminds us, Durkheim's contemporaries did not see him as the "giant" in the way we do today (see also Giddens and Pierson, 1998, p. 40).

\section{The Writings of and about Saussure}

\section{The Cours de Linguistique Générale}

Despite being a prolific writer, Saussure published very little during his lifetime, and mostly reviews of others' work. This was the result of perpetual self-doubt, frustration with the abysmal state of

\footnotetext{
${ }^{17}$ For example, Meillet published "Comment les mots changent de sens" (How words change meaning) in Durkheim's L'Annee sociologique (1904). In this article, Meillet considers the nature of semantic change and suggests that more effort is needed in isolating the social causes of language change.

${ }^{18}$ Koerner cites page 147 of the Actes du Deuxième Congrès International de Linguistes, Geneva, August 25-29, 1931.
} 
general linguistic theory, and by his own admission, he was disorganized and a procrastinator. Although there is evidence that as early as 1891 and as late as 1911 he was working on a book on general "theoretical" linguistics (Saussure, 2006, p. xvi), he was most influential as a teacher. Specifically, through the posthumously published collection of lecture notes taken during three courses in Geneva between 1906 and 1911.

Compiled by Saussure's students Charles Bally and Albert Sechehaye, the Cours was published in French in 1916, three years after Saussure's death. The specific note-takers were Albert Riedlinger (for the first course in 1906-7), Riedlinger and Charles Patois (for the second course in 1908-9), and Emile Constantin (for the third course in 1910-11). It is widely known by Saussure scholars (e.g., Engler, 2004) that Bally and Sechehaye took many liberties when organizing the student's notes, by relying mostly on Constanin's notes, reordering the topics, and coloring Saussure as much more settled on difficult issues.

Beginning with Robert Godel's 1957 work (Les Sources manuscrites du Cours de linguistique générale de Ferdinand de Saussure), subsequent scholars have critically appraised the original Cours by returning to the student's notes, along with Saussure's own notes, which now includes documents outlining a book discovered in 1996 in Saussure's family's orangery (referred to as the Orangery Manuscripts). In particular, these "original manuscripts reveal a Saussurean thought which is much less categorical than in the Cours since it often admits his doubts on important points and even uses them heuristically" (Saussure 2006:xv). The Cours was first translated into English in 1959 by Wade Baskin, and remains the translation most often cited by sociologists, although the translation by Roy Harris (1983) is considered superior (e.g., Culler, 1986, p. 151). 


\section{The Saussurean Model: Components and Pitfalls}

It is outside the scope of this article to sketch the complex diffusion of Saussurean ideas throughout the various academic disciplines, but it is safe to say his linguistics was largely ignored by his home field in both the United States and France (Dosse, 1997, p. 45; Falk, 2004, pp. 122-3). ${ }^{19}$ By the time linguists and historians of linguistics began a "return to Saussure" in the 60s and 70s, it was unavoidably "mediated by 'general structuralism"” (Puech, 2004, p. 127). Furthermore, as Saussure diffused first to the east (Russia and Prague), then north (Copenhagen), then west (New York)-primarily through the Russian linguist Roman Jakobson (Johnson, 2003, p. 172; Falk, 2004, p. 114)—before finally reemerging in France, the components of the Saussurean model were "dismembered" in piecemeal attempts to overcome epistemological and rhetorical obstacles (Angenot, 1984). This dismembering led to a few key misunderstandings.

First, Saussure argued that signifier and signified were both psychological and not, as is commonly assumed, synonyms of sign and referent, respectively. Second, and related, Saussure argued that signifier and signified were arbitrarily associated, but he did not claim that signs are arbitrarily associated with referents. Furthermore, neither of these two arguments were particularly novel for the time. Rather, Saussure's real contribution was in conceptualizing language as a system of value. The final misunderstanding being that "value" is simply another word for "meaning," but, on the contrary, Saussure argued that linguistic value was distinct from linguistic meaning. In the following, I explore each of these misunderstandings in more depth.

${ }^{19}$ The most influential linguists of the time who knew Saussure the best, Meillet (in France), Hjelmsev (in Denmark), Bloomfield and Jakobson (both in the States), took pieces of the Cours, but were each anti-Saussurean in their own ways. Hjelmsev, however, considered his "glossomastics" to be the proper heir to the Saussurean project despite important differences. 


\section{The Components of the Saussurean Model}

\section{[TABLE 1 HERE]}

In Table 1, I offer definitions of technical terms found in the Cours. Before examining the core aspects of the Saussurean model — sign, arbitrariness, and system of value — it is important to consider a few peripheral terms (see Figure 1). First, is the tripartite distinction between langage, langue, and parole.

${ }^{20}$ Saussure considered langage as language broadly conceived — encompassing psychology, physiology, pragmatics, articulation, acoustics, morphology, semantics, syntax, and speech. Both parole and langue, on the other hand, are linked to a specific community of speakers, where "the sounds of speech" (les sons de la parole) were associated with parole, while the psychological "acoustic impressions" (impressions acoutiques) were associated with langue. Parole was observable and material, while langue was only material as a psychological entity resulting from the mental impressions of sound (and their associated mental concepts). In other words, langue is "the whole set of linguistic habits which allow an individual to understand and to be understood" ([1986] 2009, p. 77). However, Saussure realizes that the linguists, as scientific observers, must abstract from langue in the mind of individuals to langue as the social collection among those in a speech community. Importantly, Saussure considers langue-not parole or langage - to be the proper subject matter of the science of linguistics. But, Saussure considers this a methodological move, and therefore sees no need to reify langue (Saussure, [1986] 2009, p. 107; Jameson, 1974, p. 15).

\section{[FIGURE 1 HERE]}

${ }^{20}$ Most treatments of Saussure only consider the distinction between langue and parole. According to Descombes (2016, p. 80), this bipartite distinction enters the English speaking community through Alan Gardiner's The Theory of Language and Speech (1932). 
A second pair of terms, syntagmatic and paradigmatic, both denote two different classes of relations in langue based on how phonological units are grouped together in the mind of a speaker. The first relates to the linear unfolding of natural speech, which "applies not only to words, but to groups of words, and to complex units of every size and kind" (Saussure, [1986] 2009, p. 148). The second Saussure labels "associative relations," and refers to the nonlinear ways words (or other phonological units) are associated in the mind. This can be either a semantic association (such that they may be more or less substitutable), or "similarity in their sound patterns" (Saussure, [1986] 2009, p. 150). While both are the consequence of parole, syntagmatic and paradigmatic refer only to the organization of langue. ${ }^{21}$

Finally, from Saussure we derive synchronic and diachronic analysis. ${ }^{22}$ The first, also referred to as static linguistics, is the study of a particular langue as if frozen in time. The analytical concept of a "linguistic system" is derived from the synchronic analysis of a langue, and for Saussure it is an entirely phonological construct. The second, also referred to as evolutionary linguistics, is the study of sound changes in langue over time and across space. Contrary to some interpretations (Merleau-Ponty, 1964, p. 86; Giddens, 1979, p. 13; e.g. Emirbayer and Maynard, 2011, p. 229), both static and evolutionary approaches relate only to langue (Edie, 1971), but Saussure did suggest that evolution always begins with parole (Saussure, [1986] 2009, p. 40,121). Furthermore, although Saussure is often characterized as privileging the synchronic (static) over the diachronic (evolutionary), it was rather that he struggled to reconcile the two in any concise and satisfying manner (Saussure, 2006, pp. 80-82; Joseph, 2012b, pp. $544-5){ }^{23}$

${ }^{21}$ A subtle point often misrepresented by later scholars (e.g. Giddens 1979:13).

${ }^{22}$ This distinction likely entered American academia through Leonard Bloomfield who reviewed the second edition of the Cours in the mid 1920s, and found little else in it that Whitney had not already suggested (Falk, 2004, pp. 108-11). In passing, Saussure also referred to idiosynchronic and panchronic analysis, but considered them ultimately futile.

${ }^{23}$ Saussure went so far as to argue that a langue does not change, but rather becomes an altogether new langue with any phonological shift. In his own words, "terms brought together in a diachronic view do not fall within the same language" (Joseph 2012b:544). That is, langue is a kind of Markov chain in which a system at time $\mathrm{T}$ evolves into an entirely different system at time $\mathrm{T}+1$. This is because, in Saussure's mind, a change in the value of 


\section{[TABLE 2 HERE]}

\section{Linguistic Signs}

A common slippage in semiotic analysis in sociology is to presume that the "signified" of the Saussurean sign is some object in the world-commonly called a "referent" in the philosophy of language. However, Saussurean linguistics is fundamentally psychological, ${ }^{24}$ which is why he states that the "linguistic sign unites, not a thing and a name, but a concept and a sound image." (Saussure, [1986] 2009, p. 6). The linguistic "sign" is a wholly mental entity comprising two components, the signifier and the signified, which function together to form the sign. ${ }^{25}$ In his words, "the two elements involved in the linguistic sign are both psychological and are connected in the brain by an associative link" (Saussure, [1986] 2009, p. 76).

The first element, the signifier, is equivalent to the mental imprint of vocalizations - which is sometimes translated as "sound-image" or "word-image" or "vocal figure" or "acoustic impression" or "sound pattern"- but not the sonic qualities of utterances, nor the physiological requirements of articulation. As Saussure emphasizes ([1986] 2009, p. 12), the "word-image stands apart from the sound itself and... it is just as psychological as the concept which is associated with it." The second, signified, Saussure described variously as "ideas," "mental images," or "concepts," and is the semantic side of langue. ${ }^{26}$

one signifier necessitates the change of the values (but not meanings) of all signifiers in the system. This does not, however, require the claim that there is no diachronic change.

${ }^{24}$ According to Bally, "Une linguistique inspirée par les idées saussuriennes doit - nous l'avons vu - tout ramener à la conscience intérieure que nous avons de la langue" (Bally, 1952, p. 156).

${ }^{25}$ Many citations to Saussure in sociology are in the context of promoting Peirce's "superior" approach to the study of signs (Rochberg-Halton, 1982; Bartmanski, 2017). It is important to note, however, that the component that most interested Saussure - the "sound-image"-is embedded in Peirce's interpretant, defined as the effect that a sign has on the mind of an interpreter, and therefore Saussure could not conduct the sort of linguistic analysis he describes in a Peircean framework.

${ }^{26}$ In the same way he did not assume that the linguistic unit could be equated to a word or a morpheme or even a single sound, Saussure did not argue that each signifier was tied to exactly one signified — contra some interpretations (Denzin 1987:3). 


\section{[TABLE 3 HERE]}

Later commentators often regarded Saussure's model of the linguistic sign as incomplete. Some argued that Saussure implied physical sound (e.g. Jakobson 1964) or implied the object in the world toward which the sign was directed (i.e. the referent) (Ogden and Richards, 1923; Benveniste, 1971; Harris, 2001, pp. 69-70; Joseph, 2004, p. 75). That is, there must be four components: two psychological and two physical. An alternative interpretation of his apparent neglect of the physical, however, was that it was outside the scope of general linguistics (Joseph, 2012b, p. 290). Furthermore, Saussure was primarily concerned not with the whole psychological entity, but rather only the sound-image (contra Emirbayer, 1997, p. 300). The totality of such acoustic impressions being linguistic structure, and which he called the "margin" between sound and idea (Saussure, [1986] 2009, p. 136).

\section{Arbitrariness}

Saussure is widely credited with the notion that sounds associate with concepts arbitrarily. ${ }^{27}$ In the Cours, he states "it [the signifier] is unmotivated, i.e. arbitrary in that it actually has no natural connection with the signified" (Saussure, [1986] 2009, p. 69). As Joseph notes (2012a, p. 265), this was not novel, because "in the Geneva of Saussure's youth, this is what everyone was saying” (see also Dosse, 1997, p. 46). Furthermore, given Saussure's classical education, the terms of the debate regarding whether language was, in essence, "natural" as opposed to "conventional" was already set by the Greek philosophers. For example, the Latin word "onomatopoeia" is derived from the Greek word "onomatopoiia," referring to the stance taken by the "naturalists" who argued the original language emerged from imitating entities in the world. In the young Saussure's essay to Pictet, he quickly dismisses this as a "childish theory"-recall the Cours boldly claiming "no one disputes the principle of the arbitrary nature of the sign" ([1986] 2009, p. 68).

\footnotetext{
${ }^{27}$ What Saussure meant by this term is discussed in Benveniste (1971) and Jakobson and Waugh (2002).
} 
Now, however, it is disputed. Many researchers find a much greater degree of motivation (sometimes called "iconicity" or "sound symbolism") in language and other "semiotic systems" (Dingemanse et al., 2015; Simone, 1995; Nänny and Fischer, 1999; Perniss, Thompson and Vigliocco, 2010; Thompson et al., 2012; e.g., Abramova and Fernández, 2016). In fact, later researchers find some sub-word sound groupings pairing with meanings with such remarkable persistence-e.g., in English /gl-/ often occurs in words relating to light or vision, such as glare, gleam, glisten, glow or /fl-/ occurs in words relating to moving or turning quickly, such as flop, flutter, flee - that they have their own name: phonesthemes.

Saussure did, however, concede that some aspects of langue were motivated. For example, sounds could be semantically motivated by other words: "For dixneuf evokes the words of which it is composed, dix ('ten') and neuf ('nine')" (Saussure, [1986] 2009, p. 157). Sounds could also be motivated by their referents, but contrary to contemporary linguists, Saussure concludes such "words are rather marginal phenomena" ([1986] 2009, p. 80). His confidence on this point is, at least partly, because he is standing on the shoulder of a giant, Whitney, the American linguist. For example, see this passage from The Life and Growth of Language, first published in 1875:

The essential difference, which separates man's means of communication in kind as well as degree from that of the other animals, is that, while the latter is instinctive, the former is, in all its parts, arbitrary and conventional...Even where the onomatopoeic or imitative element is most conspicuous - as in cuckoo and pewee, in crack and whiz - there is no tie of necessity, but only of convenience: if there were necessity, it would extend equally to other animals and other noises; and also to all tongues; while in fact these conceptions have elsewhere wholly other names (Whitney, 1875, p. 282).

Saussure makes a slight modification to Whitney's principle of arbitrariness: he moves it from a relation between sign and referent (e.g. the physical sound of the word "tree" and an actual tree) to a relation between the psychological complements of the sign and the referent (e.g. the mental impression of 
the sound of the word "tree" and the mental concept of "tree"). In so doing, Saussure sidesteps the problem of reference. In his words ([1986] 2009, p. 126):

The idea of 'sister' is not linked by any inner relationship to the succession of sounds s-ö-r which serves as its signifier in French; that it could be represented equally by just any other sequence is proved by differences among languages and by the very existence of different languages: the signified 'ox' has as its signifier /b-ö-f/ on one side of the border and /o-k-s/ on the other

Here, both speakers have the same signified for this thing in the world (i.e., an ox) to which they attach two different signifiers (/b-ö-f/ and /o-k-s/) (Benveniste, 1971, p. 44). Arbitrariness, for Saussure, stands between the mental impression of sounds and ideas, allowing him to treat the former as analytically autonomous.

\section{Language as a System of Values}

Isolating the signifier for linguistic analysis, Saussure arrives at his primary innovation (Dosse, 1997, p. 46): "system of values." ${ }^{28}$ Saussure argued the value of a linguistic unit, but not the meaning, emerged from phonological differences alone-and importantly not degrees of differences (Joseph, 2012b, p. 300). Saussure, therefore, suggests studying the "état de langue"-the state of a system of linguistic values, taken as a whole, at one point in time.

Saussure's argument that linguistic units gain their "value" by their distinction from other units in a system of langue is cited (approvingly or disapprovingly) as evidence that Saussure originated the notion that all meaning is internally constituted (Rochberg-Halton, 1982, p. 458, 1986, p. 54; Jones, 1996, p. 300; e.g. Emirbayer, 1997, p. 300; Mohr, 2005, p. 350; Tavory and Swidler, 2009, p. 172). This interpretation, however, incorporates two assumptions that Saussure did not make.

${ }^{28}$ This is sometimes depicted as a "radical break" with the philologists and comparativists which were dominant during Saussure's time and under which he studied at Leipzig. And yet, there remains much continuity between Saussure's thought and his predecessors and contemporaries. As Jameson describes it, "one can well understand how in the face of all tables of sound changes Saussure found himself little by little evolving a distinction between causes that are external to a phenomenon and causes which are somehow intrinsic to it, and this distinction may stand as the definition of the idea of system itself" (1974:7-8). 
The first problematic assumption is that the logic by which signifiers gain "value" is the very same logic by which signifieds gain "meaning" In other words, that the principle of arbitrariness applies not only to the relation between signifiers and signifieds but also the relation between the sign and the world. This is closely associated with the second assumption: when Saussure uses the term "values" this is synonymous to his use of the term "meaning"-indeed this misunderstanding is found in both Saussurean proponents and critics (Wiley, 2006, p. 327; Smith, 2011, pp. 154-5; Lash, 2014, p. 22). By making these two assumptions scholars can propose the following: signifieds have no "meaning" on their own, they only gain "meaning" by their relationship to other signifieds in a system.

Saussure, in contrast, did not consider value to be synonymous with meaning (Godel, 1957, p. 69). In fact, Reidlinger, in his notebook for the second course, writes explicitly "La valeur, ce n'est pas la signification" (Saussure, 1989, p. 248). Rather linguistic value referred to features of phonology (Joseph, 2004, pp. 65-7). This is especially clear in the following statement from the Cours: "Proof of this is that the value of a term may be modified without either its meaning or its sound being affected, solely because a neighboring term has been modified" (Saussure, [1986] 2009, p. 120). ${ }^{29}$

Saussure also did not presume signifieds were equivalent to, or entirely dictated by, the logic of the system of signifiers. Saussure uses a variety of analogies to approximate his argument that phonological units demarcated areas in a pure space of value: i.e. "langue is a form and not a substance." ${ }^{30}$ Linguistic value, for Saussure, was much more akin to mathematical value, such as the infinitesimal calculus undergirding the neoclassical revolution in economics (McCloskey, 1998, pp. 28-31). In arguing that linguistics deals with value even more "pure" than economics, Saussure states (Saussure, 2006, p. 80):

\footnotetext{
29 “La preuve en est que la valeur d'un terme peut être modifiée sans qu'on touche ni à son sens ni à ses sons, mais seulement par le fait que tel autre terme voisin aura subi une modification.” (Saussure, 1916, p. 173)

30 "La langue est une forme, non une substance" (Saussure, 1916, p. 169).
} 
...language is a system of pure values which are determined by nothing except the momentary arrangement of its terms. A value - so long as it is somehow rooted in things and in their natural relations, as happens with economics (the value of a plot of ground, for instance, is related to its productivity) - can to some extent be traced in time if we remember that it depends at each moment upon a system of coexisting values. Its link with things gives it, perforce, a natural basis, and the judgments that we base on such values are therefore never completely arbitrary; their variability is limited. But we have just seen that natural data have no place in linguistics.

\section{Conclusion}

Cultural sociologists attribute to Saussure: (1) the postulate that meaning is arbitrary (2) the idea that signs gain meaning only through relations of opposition to other signs, and (3) the view that there is an isomorphic correspondence between linguistic signs and all cultural units of analysis, ergo culture is fundamentally arbitrary, and finally (4) he presents a Durkheimian theory of culture because he was a follower of Durkheim. I have demonstrated, in contrast, that there is no evidence that Durkheim influenced (the institutionally older) Saussure, nor did he claim that linguistic meaning is arbitrary or that signs gain meaning only through relations of opposition to other signs. Finally, Saussure never intended his analytical model of phonology to apply to the operation of meaning in general. Rather, Saussure's project was specific to linguistics, and mainly one of theoretical and methodological clarification regarding phonology.

It is not unreasonable to see language as central to human culture, or even the privileged model for the operation of culture in general. However, we should be mindful of the ways Saussure is used to shut down lines of inquiry while also erasing a century of advances in linguistics. Critically examining the use of Saussurean notions in contemporary cultural sociology has several implications for future analysis (Lizardo et al., 2019). First, the arbitrariness of meaning enjoys such a central place in the backdrop of our disciplinary understanding of structuralism and post-structuralism that it may have led contemporary analysts to misread other scholars in this tradition - for example, consider a recent analysis of the role of 
motivation and pragmatics in Umberto Eco's work (Cossu, 2017). Second, alongside appeals to the authority of Saussure, scholars often assert that, if meaning is not arbitrary, it must be fixed or otherwise not "conventional," and therefore ahistorical. But this need not be the case. Following Peirce (1974), for example, there can be a continuum of arbitrariness and motivation, and to say that meaning is motivated is not to say it is determined. Objects may have a range of motivated meanings from which a few are selected. Even though this range of meanings is probabilistically constrained, the selection is nevertheless conventional. Smoke may mean fire, but also food or danger. In short, it might make our task more difficult, but it is both empirically and theoretically fruitful to challenge the assumption that meaning is necessarily arbitrary.

Some scholars will continue to justify the arbitrariness of meaning by pointing to Derrida's claim that "every signified is also in the position of a signifier" (1981, p. 20). This may be considered an anthropological constant, which humanity cannot escape-i.e. the so-called "prison-house of language" (Jameson 1974)—with affinities to "strong" social constructionism (Smith, 2011, pp. 119-206; Burr, 2015, pp. 58-61). Or, following the Frankfurt school essay "The Culture Industry: Enlightenment as Mass Deception," scholars might make an historical argument that sign systems achieve self-referential status as a result of the peculiarities of late-modern societies (see Baudrillard, 1981 in particular). Regardless of why one wishes to argue meaning is arbitrary, citing Saussure to justify such claims - as an appeal to authority—is to misinterpret his core contributions to linguistics.

\section{References}

Abramova, E. and Fernández, R. (2016) 'Questioning Arbitrariness in Language: a Data-Driven Study of Conventional Iconicity', in Proceedings of the 2016 Conference of the North American Chapter of the Association for Computational Linguistics: Human Language Technologies. San Diego, California: Association for Computational Linguistics, pp. 343-352.

Alexander, J. (1988) Durkheimian Sociology: Cultural Studies. Cambridge University Press. 
Alexander, J. (2006) The Civil Sphere. Oxford University Press.

Alexander, J. (2011) Performance and power. Polity.

Alexander, J. (2013) Trauma: A Social Theory. John Wiley \& Sons.

Alexander, J. and Smith, P. (1993) 'The discourse of American civil society: A new proposal for cultural studies', Theory and Society, 22(2), pp. 151-207.

Anderson, P. (2016) In the Tracks of Historical Materialism. Verso Books.

Angenot, M. (1984) 'Structuralism as Syncretism: Institutional Distortions of Saussure', The Structural Allegory. Reconstructive Encounters with the New French Thought, Manchester UP, Manchester.

Ardener, E. (1971) 'Introductory Essay: Social Anthropology and Language', in Ardener, E. (ed.) Social Anthropology and Language. London: Tavistock, pp. ix-cii.

Bally, C. (1952) Le langage et la vie. Librairie Droz.

Bartmanski, D. (2017) 'Social construction and cultural meaning: Reconstructing qualitative sociology', American Journal of Cultural Sociology. Palgrave Macmillan UK, pp. 1-25.

Baudrillard, J. (1981) For a Critique of the Political Economy of the Sign. Telos Press.

Benveniste, É. (1971) Problems in general linguistics. University of Miami Press.

Bouissac, P. (2010) Saussure: A Guide For The Perplexed. Bloomsbury Publishing.

Brown, R. H. (1978) A Poetic for Sociology: Toward a Logic of Discovery for the Human Sciences. CUP Archive.

Burr, V. (2015) Social Constructionism. Routledge.

Calhoun, C. (2012) Classical sociological theory. John Wiley \& Sons.

Clark, T. N. (1968) 'Emile Durkheim and the institutionalization of sociology in the French university system', Archives europeennes de sociologie. European journal of sociology. Europäisches Archiv für Soziologie. Cambridge Univ Press, 9(01), pp. 36-71.

Connell, R. W. (1997) 'Why Is Classical Theory Classical?', The American journal of sociology. journals.uchicago.edu, 102(6), pp. 1511-1557.

Cordero, R., Carballo, F. and Ossandón, J. (2008) 'Performing Cultural Sociology: A Conversation with Jeffrey Alexander', European Journal of Social Theory. SAGE Publications Ltd, 11(4), pp. 523-542.

Cossu, A. (2017) 'Signs, webs, and memories: Umberto Eco as a (social) theorist', Thesis Eleven. SAGE Publications Ltd, 140(1), pp. 74-89.

Culler, J. D. (1986) Ferdinand de Saussure. Cornell University Press.

Davies, A. M. (2004) 'Saussure and indo-european linguistics', The Cambridge Companion to Saussure. 
Cambridge University Press Cambridge, p. 9.

Derrida, J. (1981) 'Positions (A. Bass, Trans.)’. Chicago: University of Chicago Press.

Descombes, V. (2016) 'The order of things: An archaeology of what?', History and theory. Wiley Online Library, 55(4), pp. 66-81.

Dickens, D. R. (1990) 'Deconstruction and Marxist Inquiry', Sociological perspectives: SP: official publication of the Pacific Sociological Association. SAGE Publications Inc, 33(1), pp. 147-158.

Dingemanse, M. et al. (2015) 'Arbitrariness, Iconicity, and Systematicity in Language', Trends in cognitive sciences, 19(10), pp. 603-615.

Doroszewski, W. (1933) Quelques remarques sur les rapports de la sociologie et de la linguistique: Durkheim et F. de Saussure. F. Alcan.

Doroszewski, W. (1957) Le structuralisme linguistique et les études de géographie dialectale.

Dosse, F. (1997) History of Structuralism: The rising sign, 1945-1966. U of Minnesota Press.

Durkheim, É. (1924) Sociologie et philosophie. Alcan.

Durkheim, É. (1974) Sociology and Philosophy. Simon and Schuster.

Eco, U. (1995) The search for the perfect language. Wiley-Blackwell.

Edie, J. M. (1971) ‘Was Merleau-Ponty a Structuralist?’, Semiotica, 4(4). doi: 10.1515/semi.1971.4.4.297.

Elder-Vass, D. (2014) 'Debate: Seven Ways to be A Realist About Language', Journal for the theory of social behaviour. Wiley Online Library, 44(3), pp. 249-267.

Emirbayer, M. (1997) 'Manifesto for a relational sociology 1', The American Journal of Sociology, 103(2), pp. 281-317.

Emirbayer, M. (2004) 'The Alexander School of Cultural Sociology', Thesis Eleven, 79(1), pp. 5-15.

Emirbayer, M. and Maynard, D. W. (2011) 'Pragmatism and Ethnomethodology', Qualitative sociology. Springer US, 34(1), pp. 221-261.

Engler, R. (2004) 'The making of the Cours de linguistique generale', in Sanders, C. (ed.) The Cambridge Companion to Saussure. Cambridge: Cambridge University Press, pp. 47-58.

Falk, J. S. (2004) 'Saussure and American linguistics', The Cambridge Companion to Saussure.

Cambridge University Press, pp. 107-123.

Firth, J. R. (1950) 'Personality and language in society', The Sociological Review, 42(1), pp. 37-52.

Foucault, M. (2012) The Order of Things: The Archaeology of Knowledge. Vintage Books.

Gane, M. (1983) 'Durkheim: the sacred language', Economy and society. Routledge, 12(1), pp. 1-47. 
Gardiner, A. H. (1932) The theory of speech and language. Oxford Univ. Press.

Giddens, A. (1978) Durkheim. Harvester.

Giddens, A. (1979) Central problems in social theory: Action, structure, and contradiction in social analysis. Univ of California Press.

Giddens, A. and Pierson, C. (1998) Conversations with Anthony Giddens: Making Sense of Modernity. Stanford University Press.

Godel, R. (1957) 'Les Sources manuscrites du“ Cours de linguistique générale” de F. de Saussure.-Genève: Droz [usw.] 1957. 282 S. 4'. Université de Genève.

Gottdiener, M. (1985) 'Hegemony and Mass Culture: A Semiotic Approach', The American journal of sociology. journals.uchicago.edu, 90(5), pp. 979-1001.

Hagège, C. (1967) 'Extraits de la correspondance de N. S. Troubetzkoy', La Linguistique. Presses Universitaires de France, 3(1), pp. 109-136.

Harris, R. (2001) Saussure and his Interpreters. Edinburgh University Press.

Jakobson, R. and Waugh, L. R. (2002) The Sound Shape of Language. Walter de Gruyter.

Jameson, F. (1974) The Prison-house of Language: A Critical Account of Structuralism and Russian Formalism. Princeton University Press.

Johnson, C. (2003) Claude Lévi-Strauss: The Formative Years. Cambridge University Press.

Jones, M. P. (1996) 'Posthuman Agency: Between Theoretical Traditions', Sociological Theory.

[American Sociological Association, Wiley, Sage Publications, Inc.], 14(3), pp. 290-309.

Joseph, J. E. (2000) 'The Unconscious and the Social in Saussure', Historiographia linguistica, 27(3), pp. 307-334.

Joseph, J. E. (2004) 'The Linguistic Sign', in The Cambridge Companion to Saussure. Cambridge: Cambridge University Press, pp. 59-75.

Joseph, J. E. (2012a) 'Language Pedagogy and Political-Cognitive Autonomy in Mid-19th Century Geneva: The Latin manuals of Louis Longchamp (1802-1874)', Historiographia linguistica. John Benjamins, 39(2), pp. 259-277.

Joseph, J. E. (2012b) Saussure. OUP Oxford.

Kane, A. (1991) 'Cultural Analysis in Historical Sociology: The Analytic and Concrete Forms of the Autonomy of Culture’, Sociological Theory, 9(1), p. 53.

Knight, C. R. and Reed, I. A. (2019) 'Meaning and Modularity: The Multivalence of "Mechanism" in Sociological Explanation’, Sociological Theory. SAGE Publications Inc, 37(3), pp. 234-256.

Koerner, E. F. (1971) Ferdinand de Saussure: origin and development of his linguistic theory in western studies of language: a critical evaluation of Saussurean principles and their relevance to contemporary linguistic theories.--. Simon Fraser University. Theses (Dept. of Modern Languages). Available at: 
http://summit.sfu.ca/system/files/iritems1/2954/b11119603.pdf.

Koerner, E. F. K. (1983) Linguistics and Evolutionary Theory: Three Essays. New edition. John Benjamins Publishing.

Koerner, E. F. K. (1985) 'The place of Saussure's “Mémoire"in the development of historical linguistics', in Fisiak, J. (ed.) Papers from the 6th International Conference on Historical Linguistics, pp. 323-345.

Koerner, E. F. K. (1987) On the Problem of influence' in Linguistic Historiography. John Benjamin.

Koerner, E. F. K. (1991) 'Toward a History of Modern Sociolinguistics', American speech. [Duke University Press, American Dialect Society], 66(1), pp. 57-70.

Koerner, E. F. K. (2013) Ferdinand de Saussure: Origin and Development of his Linguistic Thought in Western Studies of Language. Springer-Verlag.

Krampen, M. ([1979] 2013) Meaning in the Urban Environment. Routledge.

Kronenfeld, D. and Decker, H. W. (1979) 'Structuralism', Annual review of anthropology. Annual Reviews, 8(1), pp. 503-541.

Lash, D. S. (2014) Sociology of Postmodernism. Routledge.

Lemert, C. C. (1979) 'Language, structure, and measurement: Structuralist semiotics and sociology', The American journal of sociology, pp. 929-957.

Lemert, C. C. (2003) 'Schools and Scholars Durkheim's Ghosts', Journal of historical sociology. wesscholar.wesleyan.edu, 16(3), p. 303.

Lizardo, O. et al. (2019) 'What can cognitive neuroscience do for cultural sociology?', American Journal of Cultural Sociology. doi: 10.1057/s41290-019-00077-8.

Lukes, S. (1985) Emile Durkheim, His Life and Work: A Historical and Critical Study. Stanford University Press.

Maryanski, A. and Turner, J. H. (1991) 'The Offspring of Functionalism: French and British Structuralism', Sociological Theory, 9(1), pp. 106-115.

McCloskey, D. N. (1998) The Rhetoric of Economics. Univ of Wisconsin Press.

Meillet, A. (1904) 'Comment Les Mots Changent De Sens', L'Année sociologique. Presses Universitaires de France, 9, pp. 1-38.

Merleau-Ponty, M. (1964) Signs. Translated by R. C. Maccleary. Evanston.

Meštrović, S. G. (1987) 'Durkheim's concept of anomie considered as a 'total social fact', The British journal of sociology. JSTOR. Available at: http://www.jstor.org/stable/590917.

Mohr, J. (2005) 'The discourses of welfare and welfare reform', in Blackwell Companions to Sociology. Oxford: Blackwell, pp. 346-63. 
Nänny, M. and Fischer, O. (1999) Form Miming Meaning. John Benjamins Publishing.

Ogden, C. K. and Richards, I. A. (1923) The meaning of meaning: A study of the influence of thought and of the science of symbolism. Harcourt, Brace \& World, Inc.

Peirce, C. S. (1974) Collected Papers of Charles Sanders Peirce. Harvard University Press.

Perniss, P., Thompson, R. L. and Vigliocco, G. (2010) 'Iconicity as a general property of language: evidence from spoken and signed languages', Frontiers in psychology. journal.frontiersin.org, 1, p. 227.

Puech, C. (2004) 'Saussure and structuralist linguistics in Europe', The Cambridge Companion to Saussure. Cambridge University Press, pp. 124-138.

Rawls, A. W. (1996) 'Durkheim's epistemology: the neglected argument', The American journal of sociology, pp. 430-482.

Reed, I. and Alexander, J. (2009) 'Social science as reading and performance: A cultural-sociological understanding of epistemology', European Journal of Social Theory. Sage Publications Sage UK: London, England, 12(1), pp. 21-41.

Richards, R. J. (2002) 'The Linguistic Creation of Man: Charles Darwin, August Schleicher, Ernst Haeckel, and the Missing Link in Nineteenth-Century Evolutionary Theory', in Dörries, M. (ed.) Experimenting in Tongues: Studies in Science and Language, pp. 21-48.

Rochberg-Halton, E. (1982) 'Situation, structure, and the context of meaning', The Sociological quarterly. Wiley Online Library, 23(4), pp. 455-465.

Rochberg-Halton, E. (1986) Meaning and Modernity. Chicago: Chicago University Press.

Sahlins, M. (1976) Culture and Practical Reason. University of Chicago Press.

Saussure, F. de ([1986] 2009) Course in General Linguistics. Edited by A. S. C. Bally. Translated by R. Harris. Chicago: Open Court.

Saussure, F. de (1916) Cours de linguistique générale. Payot.

Saussure, F. de (1989) Cours De Linguistique Générale: Edition Critique. Otto Harrassowitz Verlag.

Saussure, F. de (2006) Writings in General Linguistics. Oxford University Press.

Simone, R. (1995) Iconicity in Language. John Benjamins Publishing.

Smith, C. (2011) What Is a Person?: Rethinking Humanity, Social Life, and the Moral Good from the Person Up. University of Chicago Press.

Tarde, G. (2010) Gabriel Tarde On Communication and Social Influence: Selected Papers. University of Chicago Press.

Tavory, I. and Swidler, A. (2009) 'Condom Semiotics: Meaning and Condom Use in Rural Malawi', American sociological review. SAGE Publications Inc, 74(2), pp. 171-189.

Thompson, R. L. et al. (2012) 'The road to language learning is iconic: evidence from British Sign 
Language', Psychological science. journals.sagepub.com, 23(12), pp. 1443-1448.

Turner, J. H. (1987) 'Toward a Sociological Theory of Motivation', American sociological review. [American Sociological Association, Sage Publications, Inc.], 52(1), pp. 15-27.

Washabaugh, W. (1974) 'Saussure, Durkheim, and sociolinguistic theory', Archivum linguisticum. Mansell, 5, pp. 25-34.

Whitney, W. D. (1875) The Life and Growth of Language. H. S. King.

Wiley, N. (1988) ‘The Micro-Macro Problem in Social Theory', Sociological Theory, 6(2), p. 254.

Wiley, N. (2006) 'Inner Speech as a Language: A Saussurean Inquiry', Journal for the theory of social behaviour. Blackwell Publishing Ltd, 36(3), pp. 319-341.

Wuthnow, R. (1989) Meaning and moral order: Explorations in cultural analysis. Univ of California Press.

Zerubavel, E. (1987) 'The language of time: Toward a semiotics of temporality', The Sociological Quarterly, 28(3), pp. 343-356.

Zerubavel, E. (2004) 'The Social Marking of the Past: Towards a Socio-Semiotics of Memory', Matters of Culture: Cultural Sociology in Practice. Cambridge University Press Cambridge, pp. 184-195. 


\section{Figures}

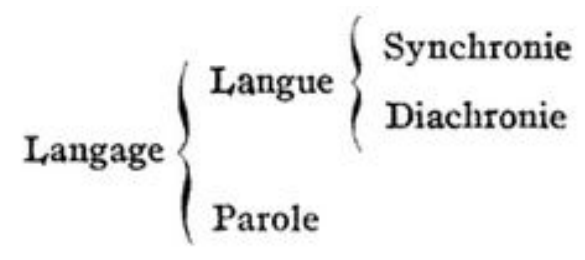

Figure 1. According to Saussure (1916:143), this table shows the "rational form" that linguistic studies should take (Le tableau suivant indique la forme rationnelle que doit prendre l'étude linguistique) 


\section{Tables}

Table 1. Key Texts by, and about, Saussure

\begin{tabular}{|c|c|c|}
\hline 1879 & $\begin{array}{l}\text { Mémoire sur le système primitif } \\
\text { des voyelles dans les langues } \\
\text { indo-européennes }\end{array}$ & $\begin{array}{l}\text { The only major work Saussure published during } \\
\text { his lifetime. The first English translation, Lehman } \\
1967 .\end{array}$ \\
\hline 1916 & Cours de linguistique générale & $\begin{array}{l}\text { Compiled by Charles Bally and Albert Sechehaye } \\
\text { from notes on lectures between } 1906 \text { and } 1911 \\
\text { (second edition 1922). }\end{array}$ \\
\hline 1957 & $\begin{array}{l}\text { Les Sources manuscrites du } \\
\text { "Cours de linguistique generale" } \\
\text { de F. de Saussure }\end{array}$ & $\begin{array}{l}\text { Robert Godel, the first exegetical text, presented } \\
\text { the sources used by Bally and Sechehaye in } \\
\text { parallel with their interpretations. }\end{array}$ \\
\hline 1959 & Course in General Linguistics & First English translation by Wade Baskin. \\
\hline 1968 & $\begin{array}{l}\text { Cours de linguistique générale: } \\
\text { Edition Critique }\end{array}$ & $\begin{array}{l}\text { Rudolf Engler's critical recompilation of the } \\
\text { original lecture notes. }\end{array}$ \\
\hline 1983 & Course in General Linguistics & Second English translation by Roy Harris \\
\hline 2002 & Ecrits de linguistique générale & $\begin{array}{l}\text { Simon Bouquet and Rudolf Engler's compilation } \\
\text { of the Orangery Manuscripts, the "lost" notes in } \\
\text { Saussure's handwriting, discovered in 1996, } \\
\text { detailing a book on general linguistics. }\end{array}$ \\
\hline 2006 & Writings in General Linguistics & $\begin{array}{l}\text { Carol Sanders and Matthew Pires' English } \\
\text { translation of Bouquet and Engler (2002) }\end{array}$ \\
\hline
\end{tabular}


Table 2. Definition of Saussure's Terms and Distinctions

\begin{tabular}{r|l}
\hline Langage & A general category, encompassing all aspects of speech \\
\hline Langue & A particular language of a community of speakers \\
\hline Pyntagmatic & $\begin{array}{l}\text { A linguistic performance (i.e. utterances) } \\
\text { sequentially to make an utterance. }\end{array}$ \\
\hline Paradigmatic & $\begin{array}{l}\text { Denotes the association between linguistic units through semantic } \\
\text { or phonological similarity. }\end{array}$ \\
\hline Synchronic & How a language (langue) exists at one point in time \\
\hline Diachronic & How a language (langue) changes through time
\end{tabular}

Table 3. The Linguistic Sign

\begin{tabular}{r|l}
\hline $\begin{array}{r}\text { Signifier } \\
\text { (in French "signifiant") }\end{array}$ & $\begin{array}{l}\text { Mental impression of phonic qualities, the "sound-image," } \\
\text { or "acoustic impression" of a linguistic unit. }\end{array}$ \\
\hline $\begin{array}{r}\text { Signified } \\
\text { (in French "signifié") }\end{array}$ & $\begin{array}{l}\text { Meaning, concept, or ideational component, to which a } \\
\text { linguistic unit is fused. }\end{array}$
\end{tabular}

